\title{
When employer brand image aids employee satisfaction and engagement
}

Article

Accepted Version

Davies, G., Mete, M. and Whelan, S. (2018) When employer brand image aids employee satisfaction and engagement. Journal of Organizational Effectiveness: People and Performance, 5 (1). pp. 64-80. ISSN 2051-6614 doi: https://doi.org/10.1108/JOEPP-03-2017-0028 Available at https://centaur.reading.ac.uk/88533/

It is advisable to refer to the publisher's version if you intend to cite from the work. See Guidance on citing.

Published version at: https://www.emerald.com/insight/content/doi/10.1108/JOEPP-03-2017-0028/full/html To link to this article DOI: http://dx.doi.org/10.1108/JOEPP-03-2017-0028

Publisher: Emerald

All outputs in CentAUR are protected by Intellectual Property Rights law, including copyright law. Copyright and IPR is retained by the creators or other copyright holders. Terms and conditions for use of this material are defined in the End User Agreement.

\section{www.reading.ac.uk/centaur}

\section{CentAUR}

Central Archive at the University of Reading 
Reading's research outputs online 


\section{When Employer Brand Image Aids Employee Satisfaction and Engagement}

\section{Structured Abstract}

Purpose. To test whether employee characteristics (age, gender, role and experience) influence the effects of employer image, for warmth and competence, on employee satisfaction and engagement.

Design/methodology. Members of the public were surveyed as to their satisfaction and engagement with their employer and their view of their employer's image. Half were asked to evaluate their employer's 'warmth' half its 'competence'. The influence of employee characteristics was tested on a 'base model' linking employer image to satisfaction and engagement using a mediated moderation model.

Findings. The base model proved valid; satisfaction partially mediates the influence of employer brand image on engagement. Age and experience, gender and whether the role involved customer contact moderate both the influence of the employer image and of satisfaction on engagement.

Research implications. Employee engagement can be influenced directly or indirectly by different aspects of the employer brand and to different extents. Employee demographics and role can influence the relationships between the employer image and both satisfaction and engagement.

Practical implications. Engagement varies with employee characteristics and both segmenting employees and promoting the employer's image differentially to specific groups are ways way to counter this effect.

Originality. The contexts in which employer image can influence employees in general and specific groups of employees in particular are not well understood. This is the first empirical study of the influence of employer image on employee engagement and one of few that considers the application of employee segmentation.

Keywords: Employer brand, segmentation, employee satisfaction, engagement, age, experience

This is a Research paper. 


\section{When Employer Brand Image Aids Employee Satisfaction and Engagement}

The potential advantages of employees having a positive view of the corporate brand, often referred to as the employee or employer brand, are widely recognised (Sparrow and Otaye, 2015; Lievens and Slaughter, 2016; Theurer, et al. 2016). These include enhanced recruitment, retention and employee engagement and commitment (Barrow and Mosley, 2005). Employer branding has developed out of corporate branding theory largely as a result of the application of ideas on influencing customers to human resource management and to its influence over potential and existing employees (Cable and Turban, 2001). But, while insights have been growing about the influence of the employer brand externally (Backhaus and Tikoo, 2004) in attracting potential employees (Rampl and Kenning, 2014) enhancing recruitment (Barrow and Mosley, 2005) and reducing the cost of doing so (Gultekin, 2011), the quantity of research into how the employee brand influences existing employees is comparatively lacking (Theurer et al. 2016). This is despite evidence that a positive view of the organisation among existing employees can enhance a range of outcomes (King and Grace, 2012) including sales growth (Davies et al., 2010) profit and growth (Mosley, 2007; Mosley 2014).

Our aim here is to understand how the symbolic employer brand can be used to influence employee satisfaction and engagement and how this influence might vary by employee related factors such as age, gender, experience and role. Specifically we test the differential effect of two prominent dimensions of employer brand image on satisfaction and engagement and then examine the potential moderating effect of employee characteristics 
on such relationships. After first presenting the idea of segmenting employees in the research and management of the employer brand, we review the literature on employer branding to propose a 'baseline' model of the relationship between employer brand image, employee satisfaction and employee engagement. We identify the issue of different dimensions of brand image being reported as having differing effects on employees and specially one issue in prior work of the relative effects of two dimensions (which we will label as 'warmth' and 'competence'). We then report the results of between subjects surveys of employees ( $n=111$ and 117) and use this data to test our baseline model using the two dimensions of image. We then test the influence on our models from employee age, gender, role and experience.

\section{Segmentation and the Employer Brand}

Actual or potential employees, as customers, might not behave towards an employer brand as a homogeneous whole. There is considerable work on the matching process between potential employees and employers, much of it based upon the idea of organisation-person fit and some on how different groups (age, ethnicity) might respond differently to the same employer brand (Lievens and Slaughter, 2016). The more general idea of segmenting potential employees into different groups so that their specific needs or characteristics can be addressed more effectively is also recognised (Moroko and Uncles, 2009). However there appears to be little or no work applying the idea of segmentation to existing employees, identifying the specific needs of different types based upon their demographics and role. Here we explore the research question of what changes, if any, need to be made in managing the employee brand for different groups of employees defined by age, gender, experience and whether the employee has a customer facing role. 
Age related factors have been linked to employee engagement in prior work (James, et al., 2011) and to employer branding effects (Lievens and Slaughter, 2016). Age has also become a more important issue for practitioners, following changes in employment legislation in many countries barring age discrimination. This has promoted the idea of employees' working longer, leading to an older workforce and a workplace where age differences and age-related issues can be expected to increase. We also chose to examine gender effects due to the complex relationship between the issue of equal pay and work-lifestyle balance between the genders (e.g. Sloane and Williams, 2000) leading to the idea that women might be less satisfied than men in the world of work due to such equality issues. Prior work is somewhat equivocal on whether engagement varies with gender and (if so) why (Schaufeli, et al., 2006; Stoeber, et al., 2013; Robinson, et al., 2007) and we wanted to explore this further. As job satisfaction (often related to overall satisfaction with an employer) has been shown to be influenced by experience (Klassen and Chiu, 2010) we decided to include the effect of experience on our base model. (In the latter study teachers were shown to be more satisfied as their experience increased their confidence to do their job). Given the relative significance of the views held of the employer brand by customer-facing employees, we were interested in any differences between those with customer-facing roles and those without. If companies have embraced internal marketing, and the idea of influencing customers attitudes by improving the attitudes of front line employees (Davies et al., 2010), customer facing employees might be expected to have more positive views of the employer brand.

\section{Employer Brand Image}


Three recent reviews of the literature on employer branding (Sparrow and Otaye, 2015;

Lievens and Slaughter, 2016; Theurer et al. 2016) emphasise the different ways of examining and defining the concept. Reflecting work on consumer brand equity, Lievens and Highhouse (2003) argue that the employer brand can be usefully seen as having two aspects, instrumental (including more tangible factors such as pay and conditions) and symbolic (including the image held of the employer) where the latter is defined as the subjective, abstract and intangible attributes associated with the organisation.

Strengthening these symbolic qualities can be expected to improve work related factors such as identification (Edwards, 2010). Prior work within this perspective has adapted the measurement of consumer brand imagery to that of the image of employers among both potential (Slaughter et al., 2004) and existing employees (Davies et al., 2002). In both instances these researchers measured employer image using the device of brand personality, developing multidimensional scales similar to those in the consumer branding literature (see for example Geuens, et al., 2009).

Such work has led to a large number of dimensions to brand personality being identified, too many to be included in a single study. Recent work using the stereotype content model (SCM), which explains how we perceive entities with humanistic associations including brands, suggests that two dimensions of corporate are universally significant. In SCM terminology these are 'warmth' and 'competence'. In prehistoric times, a 'warm' individual or group would be seen as trustworthy and present no threat; while a competent individual or group would be seen as able to enact any positive or negative intentions (Fiske, et al., 2006). A group seen as not warm but competent could be a significant threat but a group seen as warm and competent a potential ally. Failure to make such an evaluation or, worse, 
making an incorrect evaluation risked damage or death. The argument is that only those making such evaluations correctly survived, passing their genes onto modern humans who, unconsciously, still use both measures to assess other groups, such as an organisation. Hence, stereotype content thinking has been used to assess the imagery of corporate entities, where not for profit organisations were seen by the public as warmer but less competent than for profit organisations (Aaker, et al., 2010). Warmth is similar to the dimension labelled variously as Sincerity (Aaker, 1997, Agreeableness (Davies, et al., 2002) and Boy Scout (Slaughter, et al., 2004) in the brand personality literature, which also contains the dimension of competence. At issue is which is the more important of the two as, within work on employer branding, Anitha and Madhavkumar (2012) found that competence was more important in attracting employees, while Davies et al. (2002) found warmth (measured as agreeableness) more relevant in predicting employee satisfaction. More generally, warmth is argued to be more important than competence (and is evaluated first) in social situations (Fiske, et al., 2002; Fiske, et al., 2007, Cuddy, et al., 2008).

\section{The Consequences of Employer Brand Image}

In the context of existing employees, various attitudinal outcomes have been linked with improving the employer brand, including: greater employee affinity, satisfaction and loyalty (e.g. Davies, 2008), employee satisfaction and commitment (e.g. Priyadarshi, 2011), satisfaction and identification (Schlager et al., 2011) satisfaction, commitment and retention (Ito, et al., 2013) and engagement (e.g. Kunerth and Mosley, 2011).

We chose employee satisfaction and engagement as our outcome variables, as satisfaction appears to be the most commonly used outcome measure when assessing the impact of 
employer branding and because of the recent increase in interest within the management literature on engagement (Billett and Smith, 2003). Satisfaction, in the context of the employee, can be defined in a number of ways including as satisfaction with the job but here we define it as 'overall satisfaction with the employer'. Engagement is more complex being seen as a 'complex nomological network encompassing trait, state, and behavioral constructs' (Macey and Schneider, 2008). The UK's professional body for Human Resource Management offers a number of definitions including the one we adopt here: 'being positively present during the performance of work by willingly contributing intellectual effort, experiencing positive emotions and meaningful connections to other'.

\section{Hypotheses}

Our empirical approach was to first propose and test a 'base model' positing the influence of employer image on our chosen outcomes. We then use this (validated) base model to test the influence of a number of employee characteristics on the main linkages in the model.

In prior work, employee engagement and satisfaction have been seen as strongly related (Harter, et al., 2002; Saks, 2006) but with the order of influence upon each other being at issue. Here we take an employer perspective to argue engagement as the main outcome variable. The employer brand has been shown to influence both satisfaction (Davies, 2008; Priyadarshi, 2011; Schlager et al., 2011; Ito, et al., 2013) and engagement (Kunerth and Mosley, 2011). Our base model connecting all three constructs that this prior work implies is shown in Figure (1). 
Take in Figure 1 here

Our base model has three hypothesised links. From prior work on the relationship between employer brand image and employee satisfaction (Davies, 2008; Priyadarshi, 2011; Schlager et al., 2011; Ito,et al. 2013) we can propose:

H1a: The more positive employee views are of their employer's image, the greater their satisfaction

From the work of Kunerth and Mosley (2011) and others on the relationship between employer branding and engagement we can also propose:

H1b: The more positive employee views are of their employer's image, the greater their engagement.

Following Harter, et al.(2002) and Saks (2006) we would expect employee satisfaction and engagement to be positively linked hence:

H2: The greater is employee satisfaction, the greater their engagement.

In effect employee satisfaction is in a potentially mediating role between employer brand image and employee engagement, implying:

H3: The effects of employee views of their employer's image on their engagement are mediated by their satisfaction.

Different aspects of employer image have been shown to have different effects on outcome variables. For example Davies (2008) showed that employee satisfaction was largely influenced by how 'agreeable' (trustworthy, supportive) the employer brand was perceived to be, while loyalty (measured by how long an employee had been employed) was more influenced by how enterprising (exciting, daring) and chic (stylish, prestigious) the employer was seen. We are specifically concerned to test which of warmth and competence is more 
associated with satisfaction and engagement, given the conflicting findings of Anitha and Madhavkumar (2012) and Davies et al (2002).

From such prior work we can however propose:

\section{H4: The effects of employer image will vary with the dimension of brand image}

Our main expected contribution is an understanding of whether the differences between how employee characteristics influence satisfaction and engagement might be mitigated by differences in how such employee groups react to employer imagery, such that differences in employee satisfaction between employee groups might be countered by varying the presentation of the employer's image. Put another way is there a need or a value in segmenting employees into groups that respond to employer branding in different ways? Our earlier review of the possible effects of employee characteristics on engagement and satisfaction (e.g. James et al., 2011; Schaufeli et al., 2006; Klassen and Chiu, 2010) suggested that the links in Figure 1 might indeed be influenced by employee specific factors. Our final and main hypothesis is then to test this:

H5: The relationships between employer image and both employee satisfaction and engagement can be influenced by employee specific factors.

\section{Methods}

We chose, drawing upon the stereotype content model, to measure two aspects of employer's brand image 'warmth' and 'competence'. Prior work on measuring brand imagery using a multidimensional measure has tended to ask respondents to assess a brand along each of a number of dimensions of brand image in the same questionnaire. But, as Slaughter, et al. (2004) point out, this can create a halo effect in the evaluations of individual 
dimensions. The stereotype content model also argues that warmth is assessed before competence, implying an order effect when evaluating the two. To avoid both issues we used a between subjects research design asking one half of our survey to evaluate their employer for 'warmth' and the other half for 'competence'. In each case we used the corporate brand personality measures of Davies et al. (2004) supplemented with items from Aaker, Vohs and Mogilner (2010) to provide 15 items for each dimension of employer brand image. (Appendix 1). We took our 5-item measure of satisfaction (with the company and not with the job) from Davies et al. (2004) (: recommend to others, happy to be associated with, affinity towards, good reputation and overall satisfaction). Our measure of engagement was the 9-item measure of Soane et al. (2012), which contains three sub-factors, intellectual engagement, (e.g. I focus hard on my work), social engagement (e.g. I share the same work values as my colleagues), and affective engagement (e.g. I feel positive about my work). To minimise any common methods variance effects, the response scales were varied. Satisfaction and engagement were measured using a 7 point scale with three markers $1=$ strongly disagree, 4= neither agree nor disagree and $7=$ strongly agree, but in the online survey the scales were shown using different types of layout. Brand image was measured using a 5 point scale with each point labelled from $1=$ strongly disagree to $5=$ strongly agree. We included a relatively large number of items in our image measures as we wished to explore whether there were any traits of employer brand imagery that might be more relevant than others.

Our chosen sample universe was of all (full time) employees and we surveyed members of the public as to their views of their own employer (rather than the employees of a limited number of companies). This approach also ensured that we included different types of 
employer. We used the services of an on-line panel whose membership reflects that of the adult population of the UK (Pureprofile) to recruit respondents. Filter questions ensured that respondents were employed (but not self-employed) and were working for their employer for more than 25 hours per week.

Respondents were randomly assigned to one of the two versions of our survey which differed only in the questions asked about employer brand image. The 'Competence' survey yielded 107 valid responses, while the 'Warmth' survey yielded 111. All compound measures were checked for reliability using Cronbach alpha and found to be well above the threshold of 0.7 (Appendix 1). Each was also converted into a normalised score (i.e. centred on zero with a standard deviation of 1.0).

\section{Results}

First the base model (Figure 1) was tested using the data from each survey. For this and the later analyses we used the regression models from the Hayes (2012) PROCESS macro. In Table 1, Model 1 in each case just examines the influence of the image dimension (either warmth or competence) on Engagement. Model 2 introduces the influence of both Satisfaction and Employer Image on Engagement. In each case, all links in the model shown in Figure 1 proved significant, confirming our base model and supporting hypotheses $\mathrm{H} 1 \mathrm{a}-$ H2. In each case, employee satisfaction partially, but significantly (Sobel test ${ }_{\text {Warmth }} p<.0001$; Sobel test competence $\mathrm{p}<.0001)$ mediated the effect of brand image on employee engagement, supporting $\mathrm{H} 2$. Warmth had the stronger influence on both satisfaction and engagement, compared with Competence, supporting $\mathrm{H} 4$ that the effects on outcomes such as satisfaction and engagement vary by image dimension and confirming the prior work of 
Davies et al. (2002) and the stereotype content model that warmth has a greater effect than competence.

\section{Take in Table 1 here.}

Of particular interest was to see how or whether these base model effects change when the characteristics of respondents are introduced into the model. We tested this by examining the idea that employee characteristics might influence the base model by moderating the (significant) relationships between image and the two outcome variables of employee satisfaction and engagement, Figure 2.

Take in Figure 2 here

Hence in Figure (2) the moderating term (the employee specific variable such as age) is shown as potentially influencing the relationships between employee views of employer image and both employee satisfaction and engagement.

\section{Age Effects}

\section{Take in Table 2 here}

There were some small and non-significant differences between the age profiles for each survey group, Table (2) and the data from both surveys showed differences when age was used as a moderating variable for our base model. For a moderating variable to influence the relationship between an independent and dependent variable, the interaction term between the moderating variable and the independent variable should be significant in influencing the dependent variable (while at the same time the relationship being 
moderated should change). In this case, this is the interaction term between age and either employer image (measured by either competence or warmth) or satisfaction in predicting engagement. In Table (3) we show the results for our analyses for each dimension of Brand image.

\section{Take in Table 3 here}

Age had a significant moderating effect for the influence of both Warmth and Competence on Engagement, but its effects differed. In both cases the introduction of age as a moderator made the direct influence of brand image on Engagement non-significant. (Its indirect effect via Satisfaction was still significant). For the Competence model, employee age also fully moderated the direct effect of Satisfaction on Engagement and the (negative) effect of age is via its interaction with image. For Warmth, the influence of Satisfaction on Engagement was not fully moderated but the interaction term between with Age and Satisfaction was found to be negative. The conditional direct analyses offer an explanation for the differences. In the case of Warmth, the effect of Age as a moderator on the relationship between image and Engagement is not significant for younger respondents (those aged 35 and under) but it is for their older colleagues. In the case of Competence, the moderating effect of Age on the relationship between image and Engagement is not significant for older respondents (those aged over 55) but it is for those younger. Age has then a complex influence on our base model and one dependent upon the image dimension being considered; while Age did not correlate with Competence, it influenced (negatively) the effect of Competence on Engagement. Overall, Age was positively correlated with Warmth; but while it also correlated positively with Engagement, it had both positive and 
negative effects on the relationships in the base model; in particular, increasing Satisfaction did not have as positive effect on Engagement among older employees.

\section{Gender Effects}

The gender split of respondents in both surveys was similar: Warmth, $63 \%$ male, Competence, $65 \%$ male (and similar to the national picture of $63 \%$ of full time employees being male). The effects from Gender on our base model are limited to a significant effect on the model for Warmth, Table (4), where the interaction term between Gender and Satisfaction is negative. As we coded male respondents as 1 and female as 2 , this implies that males report higher Engagement levels for a given level of Satisfaction. As Satisfaction mediates the effect of image on Engagement, this also implies that if the employer brand image for Warmth increases, it has a greater influence on the Engagement of male employees. We confirmed this by examining the relative correlation coefficients between Warmth and Satisfaction and between Warmth and Engagement. In both, the correlation coefficients were higher for male than for female employees.

\section{Take in Table 4 here}

There was little difference in the way the genders responded to the individual image measurement items for Warmth (on only one item 'straightforward' did males rate their employer significantly higher than females $(p=.006))$ but there were more differences in the responses to the engagement measure, with women evaluating each question of the 9 questions lower on average, sometimes significantly so, Table (5).

\section{Take in Table 5 here}

The scores for engagement among males were significantly higher than for females in the group evaluating Warmth, Engagement $\mathrm{M}_{\mathrm{M}}=5.30$, Engagement $_{\mathrm{F}}=4.74(p=.009)$, and the same 
was true for the combined sample Engagement ${ }_{M}=5.30$, Engagement $t_{F}=4.76(p=.003)$. Such differences between the genders appear more significant than those reported in the literature, but are in a similar direction (Schaufeli, et al., 2006; Stoeber, et al., 2013; Robinson, et al., 2007). The mean scores for Satisfaction were also higher for males but the difference was not as significant $(p=.040)$. The literature on job satisfaction (we measured overall satisfaction with the employer) however suggests that women report higher overall job satisfaction than men (Sousa-Poza and Sousa-Poza, 2003) but such surveys are of all employees, both full and part-time. We return to this issue later.

\section{Experience}

We assessed experience in two ways, asking for the number of years the respondent had worked for their current employer and also the total number of years they had been at work. No effects were apparent by introducing the experience with the current employer into our model, which is surprising as tenure is often significant in studies of employee attitudes (see for example, Grizzle, et al., 2009). The effects of including the total number of years worked was significant and similar to that when respondent age had been included (the two variables were strongly correlated, $p<.001$ ) with the exception of the nonsignificant interaction effect this time (between Experience and Satisfaction) for the Warmth equation.

\section{Take in Table 6 here}

\section{Role Effects}

We asked respondents whether or not they had customer contact as part of their role; $32 \%$ did not and $68 \%$ did. When we tested this as a mediator in our base model, Customer Contact had a significant effect on the model for Warmth but not that for Competence. 
Table (7) shows the data where having Customer Contact was coded 1 and 'not' coded 2. Both interaction terms are significant and the variable fully moderates the direct influence of Satisfaction on Engagement. The interactions are complex but, for a given level of Warmth, increasing the Satisfaction of backroom staff had a greater influence on their Engagement.

\section{Take in Table 7 here}

Those who had customer contact in their role reported significantly higher levels of Warmth $(p=.004)$, Satisfaction $(p=.023)$ and Engagement $(p=.003)$. While this is probably good news, for employers, in that prior work suggests benefits from maximising the attitudes of customer-facing staff (Davies et al., 2010), the low average scores returned by those 'in the backroom' (on our 5 point scale) for specific image traits should give cause for concern, Table 8.

\section{Take in Table 8 here}

\section{Facets of Engagement}

We analysed our age data in more detail. Our measure of Engagement (Soane et al., 2012) has three sub-components, intellectual engagement, (e.g. I focus hard on my work) social engagement (e.g. I share the same work values as my colleagues) and affective engagement (e.g. I feel positive about my work). We repeated the previous analysis substituting the full measure of Engagement with each of its components in turn as the main dependent variable for both dimensions of employer brand image. The results for Competence 
reflected that for overall engagement, but with lower levels of significance. Of greater interest were the results for Warmth, Table (9). The strongest result was for the prediction of affective engagement, where the interaction terms were both highly significant, but opposing. Increasing Warmth had a more positive effect on Satisfaction for older employees, but this effect was counteracted by the lesser effect of Satisfaction on affective engagement for the same group.

\section{Take in Table 9 here}

In summary, in considering $\mathrm{H} 5$ that employee characteristics can influence the relationships between employer image, Satisfaction and Engagement, we find support for most but not all of the factors tested and not always for both dimensions of employer brand image.

\section{Influencing Satisfaction and Engagement}

Next we identified the individual traits where there appeared to be the greatest potential to improve Satisfaction and Engagement for all groups. To do so we used all the individual traits from each image dimension in regressions to predict either employee Satisfaction or Engagement.

Only one Warmth trait emerged as significant at $p<.05$ in predicting engagement, which was 'sincere' ( $p=.04)$; but when stepwise regression was used, two traits were retained 'sincere' $(p=.001)$ and 'socially responsible' $(p=.008)$. Together they predicted $51.6 \%$ of the variance in Engagement. In predicting Satisfaction, two traits emerged as significant, 
'straightforward' ( $p=.046)$ and 'concerned' ( $p=.032)$; and when using stepwise regression, three traits were retained 'pleasant' $(p=.001)$, 'concerned' $(p<.000)$ and 'straightforward' $(p=.017)$. Together they predicted $76.5 \%$ of the variance in Satisfaction.

In predicting Engagement from the Competence traits, 'reliable' $(p=.049)$ and 'hardworking' $(p=.046)$ emerged as significant; and in the stepwise version three items, 'reliable' $(p=.001)$, 'hardworking' ( $p=.002)$ and 'intelligent' $(p=.006)$, which together predicted $51.8 \%$ of the variance in engagement. In predicting Satisfaction, 4 traits were significant 'reliable' $(p=.007)$, 'intelligent' $(p=.011)$, 'efficient' $(p=.011)$ and 'confident' $(p=.046)$; and when using stepwise regression, three traits were retained, 'intelligent' $(p=.005)$, 'reliable' $(p<.000)$ and 'efficient' $(p=.007)$. Together they predicted $59.6 \%$ of the variance in Satisfaction.

In summary, among the 30 traits we had included in our surveys, the most consistent in (positively) influencing Satisfaction and Engagement were 'reliable', 'sincere', 'concerned' and 'straightforward'. For individual companies the pattern of influence is likely to vary but the high levels of variance these predict in both our dependent variables suggest they might be useful for all firms to consider in their communication to existing employees.

\section{Discussion and Conclusions}

\section{Summary of findings}

We proposed and tested 5 hypotheses, most of which were fully supported by our data, Table 10.

Take in Table 10 here 
Our base model tested the idea that employer imagery influences employee satisfaction and employee engagement. Our data showed strongly significant relationships for both Warmth (e.g. honest and trustworthy) and Competence (e.g. reliable and effective). The stereotype content model argues that Warmth evaluations take primacy over those for Competence (Cuddy, et al., 2008). Both dimensions proved important in predicting both outcomes, but Warmth proved to be the more important of the two dimensions, a view also compatible with work on corporate branding where the similar dimension labelled as 'Agreeableness' predicts the largest share of employee satisfaction (Davies, et al., 2002).

Our baseline model shows very high $\mathrm{R}^{2}$ levels in predicting Engagement and we were careful to minimise common methods variance, which can often explain some of such effects. For example the $\mathrm{R}^{2}$ from a combination of Competence and Satisfaction was 0.60 and for a similar combination of Warmth and Satisfaction 0.55 . For the image variables alone, the figures were 0.55 for Warmth and 0.49 for Competence. Clearly managing employer brand image can contribute both positively and substantially to Engagement and could be a way to mitigate other influences.

We tested the potential impact of various types of employee related variables on the relationships between employer image and the two outcome variables. We found significant effects for age, overall experience, whether the employee's role involved customer contact and for gender, but not for or experience with the current employer. The effects on the relationships governed by Warmth and Competence differed and the influence of Warmth over the two outcomes proved more sensitive to differences in respondent type and role. The practical consequences of this are that different groups within the workplace can be 
expected to react differently to the same initiatives aimed at promoting the employer brand.

\section{Implications for theory and research}

Our work shows that older employees and male employees can be expected to react more positively in terms of their satisfaction and engagement to improvements in how Warm and/or Competent the employer brand is perceived to be, demonstrating that the idea of segmentation, already argued to be relevant to employer branding to potential employees (Moroko and Uncles, 2009), is highly relevant to the context of existing employees. As younger and/or female employees reported lower Satisfaction and Engagement, the practical challenges implied are that such groups might currently need a greater focus in the workplace. One purpose of employer branding is to create a coherent culture within the organisation (Backhaus and Tikoo, 2004) but our findings suggest that the employer brand might be presented differentially to specific groups to counter differences in how they react to the same imagery and counter any fundamental differences in their basic levels of engagement.

The effects we found from employee related variables were often complex. For example the effect of Age interacting with Competence on engagement was negative, while the same effect with Warmth was positive. Engagement levels were higher for those aged 55+ than for younger workers, although the respective Satisfaction levels did not differ and age effects were most marked in our data in explaining affective Engagement. This picture is compatible with some prior work that suggests that job satisfaction increases with age (Klassen et al., 2010) but not with that which sees the relationship as a U shaped curve, with 
job satisfaction declining in one's early years before it increases (Clark, et al., 1996). From our work, the influence of employer image clearly differs with age, although the mechanism for doing so is complex. Younger employees reported lower Engagement, particularly intellectual engagement. There is little in the literature as to how to engage such employees, other than rather folksy advice to employers to make their workplace more 'cool' (Ferri-Reed, 2010). There is far more published work about engaging older employees (e.g. Kordbacheh, et al., 2014). Our work suggests a need to focus more on the younger employee.

Gender proved important as a moderator for the influence of the Warmth aspect of the employer brand, and female respondents reported lower levels of Engagement. The differences in Engagement were also significant in our Competence survey data and were particularly marked for the two facets of social and affective Engagement. Given the current debate around equality at work, this finding is worrying. One possible explanation, from the existing literature, is that a woman's engagement might be divided between work and home (Kong, 2009). Another is that the construct of engagement is gendered and that it is easier for male workers to demonstrate 'engagement' (Banihani et al., 2013).

At issue then is whether our findings on gender effects might be due to the lack of gender neutrality in how we measured Engagement. If however our findings are valid, in that female employees are less engaged, then this has implications for the debate on equality in employment, an issue well beyond the scope of our paper. However, within the context of our work, Brammer et al., (2007) found support for their hypothesis that the relationship between CSR and employee commitment was stronger for females, suggesting one 
opportunity for gender-specific employer image building that might counter any gender specific differences in engagement.

Prior work has tended to assess the relative effect of different dimensions of brand image on outcomes such as Satisfaction by including multiple dimensions in the same regression and measuring them in the same survey instrument. The ability of one dimension to explain more variance in the target variable in such a context has been used to imply that one dimension is far more important than another (Slaughter, et al., 2004; Davies, 2008). Here we tested two dimensions independently and often found similar levels of effect, suggesting that both can be used to manage and influence engagement. However our data also show that promoting warmth will have the greater effect.

\section{Implications for practice}

The base model provides an understanding of how employer imagery can be used to support the development of Engagement, directly or via Satisfaction. As some employee specific variables totally moderated the direct influence of employer brand imagery on Engagement, the indirect effect of brand image via Satisfaction is important to consider both theoretically and practically. The implication is that an improvement in Engagement is often mainly, or only, via an improvement in Satisfaction. Most organisations undertake regular reviews of employee satisfaction, but how many include questions about how much their employees trust them or see them as competent? Such attitudes are antecedents of both Satisfaction and Engagement and should be monitored regularly. The items that proved most salient in our work and the questions they imply are whether the employer is 
seen as 'reliable', 'sincere', 'concerned' and 'straightforward' and these could be easily incorporated into an employee satisfaction survey.

Our work has focussed on the attitudes of existing employees and how the employer brand can be used to enhance satisfaction and engagement. Another option for practitioners is to use the employer brand to attract employees who are more likely to be positively influenced, once they join, by the current internal view of the brand. This in turn emphasises the need to align the internal and external promotion of the corporate brand (Hatch and Schultz, 2001).

Another practical issue allied to our work concerns who is responsible for employer branding in organisations. The same corporate brand can and will influence all stakeholders. In companies where the corporate brand is masked by the strength of individual product brands, the responsibility for brand management is clearly divided between product and corporate branding. In such contexts, brand marketing may not recognise any responsibility for employer branding. But do many human resource management (HRM) functions both recognise and accept responsibility either? Alternatively do those responsible for the customer-facing aspects of branding recognise a role in employer branding?

\section{Implications for future work}

There are case examples of HRM promoting employer branding internally (e.g. Sartain, 2005), but we lack a wider picture. The corporate brand is, arguably, fundamentally the same for both customers and employees. Employees will certainly be conscious of the imagery being promoted to customers and may well be customers themselves. Research is 
needed into how best to manage the customer and employee aspects of the corporate brand simultaneously and what it means to do so.

Future research could usefully examine how employees might be differentially influenced by employee-specific employer branding initiatives, such as CSR, which we mentioned earlier. In our study for example women and men reported similar levels for Warmth but men reported higher average values for Competence, implying that one way to enhance the engagement of female employees is to offer targeted evidence of Competence in internal marketing. There were no significant differences on any individual items to guide us further and future work is needed to identify why the genders differ.

We considered only two aspects of employer image, citing the stereotype content model to justify our choice. The effects we identified sometimes differed by the dimension we considered and further work might identify different issues if it considers other, for example, more negative aspects of employer image.

Employee engagement has become a popular concept in a number of literatures. Prior research has found a large number of factors that can influence engagement (see the reviews of Robertson-Smith and Marwick, 2009 and Gibbons, 2006), but we could find no other empirical study of the role of the employer brand in promoting engagement. Given 
the high level of explanation of engagement by employer brand image in our study, this represents a significant gap in the literature.

While we have considered demographic influences on the way engagement is created, we have not considered any psychographic influences. Prior work suggests that the personality of the employee can influence their engagement (Robinson, et al., 2007). It would be useful to consider personality and other psychographic variables as potential moderators in our base model. 


\section{References}

Aaker, J. L. (1997), "Dimensions of Brand Personality", Journal of Marketing Research, Vol. 34, pp. 347-356

Aaker, J., Vohs, K. D., and Mogilner, C. (2010), "Nonprofits are seen as warm and for-profits as competent: Firm stereotypes matter", Journal of Consumer Research, Vol. 37 No.2, pp. 224-237.

Anitha, J. and Madhavkumar, V., (2012), "A study on the impact of personality characteristics on employer attractiveness", Journal of Contemporary Research in Management, Vol. 7 No. 3, pp.11-19.

Backhaus, K., and Tikoo, S. (2004), "Conceptualizing and researching employer branding", Career Development International, Vol. 9 No. 5, pp. 501-517.

Banihani, M., Lewis, P., and Syed, J. (2013), “Is work engagement gendered?”, Gender in Management: An International Journal, Vol. 28 No. 7, pp. 400-423.

Barrow, S., and Mosley, R. (2005), The employer brand, bring the best of brand management to people at work, Wiley: London.

Billett, S. and Smith, A. (2003), "Compliance, engagement and commitment: Increasing employer expenditure in training", Journal of Vocational Education and Training, Vol. 5 No.3, pp. 281-300.

Brammer, S., Millington, A., and Rayton, B. (2007), "The contribution of corporate social responsibility to organizational commitment",The International Journal of Human Resource Management, Vol. 18 No. 10, pp.1701-1719.

Cable, D. M., and Turban, D. B. (2001), "Establishing the dimensions sources and value of job seekers employer knowledge during recruitment", Research in Personnel and Human Resources Management, Vol. 20, pp. 115-164.

Cuddy, A. J., Fiske, S. T., and Glick, P. (2008), "Warmth and competence as universal dimensions of social perception: The stereotype content model and the BIAS map", Advances in Experimental Social Psychology, Vol.40, pp.61-149.

Clark, A., Oswald, A., and Warr, P. (1996), "Is job satisfaction U-shaped in age?", Journal of Occupational and Organizational Psychology, Vol. 69 No. 1, pp. 57-81.

Davies, G. (2008), "Employer branding and its influence on managers", European Journal of Marketing, Vol. 42 No. 5/6, pp. 667-681.

Davies, G., Chun, R., and Kamins, M. A. (2010), "Reputation gaps and the performance of service organizations", Strategic Management Journal, Vol. 31 No. 5, pp. 530-546. 
Davies, G., Chun, R., da Silva, R.V. and Roper, S. (2002), Corporate Reputation and Competiveness, Routledge, London.

Edwards, M. R. (2009), “An integrative review of employer branding and OB theory", Personnel Review, Vol. 39 No.1, pp. 5-23.

Ferri-Reed, J. (2010), "The keys to engaging millennials", The Journal for Quality and Participation, Vol. 33 No.1, pp.31-33.

Fiske, S.T., Cuddy A. J. C. and Glick, P. (2006), "Universal dimensions of social cognition: warmth and competence", Trends in Cognitive Science, Vol. 11 No.2, pp. 77-83

Fiske, S. T., Cuddy, A. J. C., Glick, P., and Xu, J. (2002), "A model of (often mixed) stereotype content: competence and warmth respectively follow from perceived status and competition", Journal of Personality and Social Psychology, Vol. 82 No. 6, pp. 878-902.

Geuens, M., Weijters, B. and de Wulf, K (2009), "A new measure of brand personality", International Journal of Research in Marketing, Vol. 26, pp.97-107.

Gibbons, J. (2006), Employee Engagement: A Review of Current Research and Its Implications, The Conference Board, New York, NY, pp. 1-21.

Grizzle, J. W., Zablah, A. R., Brown, T. J., Mowen, J. C., \& Lee, J. M. (2009), “Employee customer orientation in context: how the environment moderates the influence of customer orientation on performance outcomes", Journal of Applied Psychology, Vol. 94 No. 5, pp. 1227-1242.

Gultekin, E. (2011). "What's the value of your Employment Brand?" LinkedIn Talent, retrieved from https://business.linkedin.com/talent-solutions/blog/2011/12/whats-thevalue-of-your-employment-brand (accessed 12 November 2016)

Harter, J. K., Schmidt, F. L., and Hayes, T. L. (2002), "Business-unit-level relationship between employee satisfaction, employee engagement, and business outcomes: a metaanalysis", Journal of Applied Psychology, Vol. 87 No. 2, pp. 268-279.

Hatch, M.J. and Schultz, M. (2001), "Are the strategic stars aligned for your corporate brand?" Harvard Business Review, Vol. 79 No.2, pp.128-13.

Hayes, A. F. (2012), "PROCESS: A versatile computational tool for observed variable mediation, moderation, and conditional process modelling" [White paper]. Retrieved from http://www.afhayes.com/ public/process2012.pdf. 12 November 2016. Models 4 and 15.

Ito, K.J., M. Brotheridge, C., \& McFarland, K. (2013), “Examining how preferences for employer branding attributes differ from entry to exit and how they relate to commitment, satisfaction, and retention", Career Development International, Vol 18 No.7, pp. 732-752. 
James, J. B., McKechnie, S., and Swanberg, J. (2011), "Predicting employee engagement in an age-diverse retail workforce", Journal of Organizational Behavior, Vol. 32 No.2, pp.173196.

King, C., and Grace, D. (2012). Examining the antecedents of positive employee brandrelated attitudes and behaviours. European Journal of Marketing, Vol. 46 No. 3/4, pp. 469488.

Klassen, R. M., and Chiu, M. M. (2010), "Effects on teachers' self-efficacy and job satisfaction: Teacher gender, years of experience, and job stress", Journal of Educational Psychology, Vol. 102 No. 3, pp. 741-756.

Kong, Y. (2009), "A study on the job engagement of company employees." International Journal of Psychological Studies, Vol. 1 No.2, pp. 65-68.

Kordbacheh, N., Shultz, K.S. and Olson, D.A. (2014), “Engaging mid and late career employees: The relationship between age and employee engagement, intrinsic motivation, and meaningfulness", Journal of Organizational Psychology, Vol. 14 No. 1, pp.11-25.

Kunerth, B., and Mosley, R. (2011), "Applying employer brand management to employee engagement". Strategic HR Review, Vol. 10 No.3, pp. 19-26.

Lievens, F., and Highhouse, S. (2003), "The relation of instrumental and symbolic attributes to a company's attractiveness as an employer", Personnel Psychology, Vol. 56 No.1, pp.75102.

Lievens, F., and Slaughter, J. E. (2016), “Employer image and employer branding: What we know and what we need to know", Annual Review of Organizational Psychology and Organizational Behavior, Vol. 3, pp.407-440.

Macey, W. H., and Schneider, B. (2008), "The meaning of employee engagement", Industrial and Organizational Psychology, Vol. 1 No.1, pp.3-30.

Moroko, L., \& Uncles, M. D. (2009), “Employer branding and market segmentation”, Journal of Brand Management, Vol. 17 No. 3, pp. 181-196.

Mosley, R. W. (2007), "Customer experience, organisational culture and the employer brand", Journal of Brand Management, Vol. 15 No. 2, pp. 123-134

Mosley, R. (2014) "Employer brand management: Practical lessons from the world's leading employers". John Wiley \& Sons, Chichester, UK.

Priyadarshi, P. (2011), "Employer brand image as predictor of employee satisfaction, affective commitment and turnover", Indian Journal of Industrial Relations, Vol. 46 No. 3, pp. 510-522. 
Rampl, L.V., and Kenning, P. (2014), "Employer brand trust and affect: linking brand personality to employer brand attractiveness, " European Journal of Marketing, Vol. 48 No.1/2, pp. 218-236.

Robertson-Smith G. and Marwick, C. (2009), Employee Engagement A Review of Current Thinking, Report No.469, Brighton, Institute for Employment Studies.

Robinson D., Hooker H. and Hayday S. (2007), Engagement: The Continuing Story, Report No.447, Brighton, Institute for Employment Studies.

Saks, A. M. (2006), "Antecedents and consequences of employee engagement", Journal of Managerial Psychology, Vol. 21 No.7, pp. 600-619.

Sartain, L. (2005), "Branding from the inside out at Yahoo!: HR's role as brand builder", Human Resource Management, Vol. 44 No.1, pp.89-93.

Schaufeli, W. B., Bakker, A. B., and Salanova, M. (2006), "The measurement of work engagement with a short questionnaire a cross-national study", Educational and Psychological Measurement, Vol 66 No.4, pp.701-716.

Schlager, T., Bodderas, M., Maas, P. and Luc Cachelin, J. (2011), "The influence of the employer brand on employee attitudes relevant for service branding: an empirical investigation", Journal of Services Marketing, Vol. 25 No.7, pp.497-508.

Slaughter, J. E., Zickar, M. J., Highhouse, S., and Mohr, D. C. (2004), "Personality trait inferences about organizations: development of a measure and assessment of construct validity", Journal of Applied Psychology, Vol. 89 No. 1, pp. 85-103.

Sloane, P. J., and Williams, H. (2000), "Job satisfaction, comparison earnings, and gender", Labour, Vol. 14 No.3, pp.473-502.

Soane, E., Truss, K., Alfes, K., Shantz, A., Rees. C., and Gatenby, M. (2012), “Development and application of a new measure of employee engagement: the ISA Engagement Scale", Human Resource Development International, Vol. 15 No. 5, pp. 529-547.

Sousa-Poza, A. and Sousa-Poza, A.A. (2003), "Gender differences in job satisfaction in Great Britain, 1991-2000: permanent or transitory?", Applied Economics Letters, Vol. 10 No.11, pp.691-694.

Sparrow, P., and Otaye, L. (2015), "Employee Branding: From attraction to a core HR Strategy", White Paper. Lancaster University: Management School.

Stoeber, J., Townley, J., and Davis, C.R. (2013) Comparing two work-engagement scales: Relationships with job satisfaction, organizational commitment, and workaholism (Research report, 7 April 2013). School of Psychology, University of Kent. 
Theurer, C. P., Tumasjan, A., Welpe, I. M., and Lievens, F. (2016), “Employer Branding: A Brand Equity-based literature review and research agenda". International Journal of Management Reviews. doi:10.1111/ijmr.12121 


\section{Appendix 1}

Measures of Warmth: The organisation I work for is a friendly organisation. In addition to 'friendly' we included: honest, sincere, straightforward, pleasant, trustworthy, reassuring, supportive, agreeable, concerned, socially responsible, ethical, cheerful, warm, open.

Measures of Competence: The organisation I work for is a reliable organisation. In addition to 'reliable' we included: secure, hardworking, ambitious, achievement oriented, leading, technical, corporate, effective, efficient, competent, successful, strong, intelligent.

Sources: Davies et al (2002) Aaker, Vohs and Mogilner (2010).

Reliability analysis

\begin{tabular}{|l|c|}
\hline Measure & Cronbach Alpha \\
\hline Warmth & .98 \\
\hline Satisfaction (warmth survey) & .97 \\
\hline Engagement (warmth survey) & .95 \\
\hline Competence & .96 \\
\hline Satisfaction (competence survey) & .95 \\
\hline Engagement (competence survey) & .94 \\
\hline
\end{tabular}


Tables and Figures

\begin{tabular}{|l|l|l|l|l|}
\hline $\begin{array}{l}\text { Model and } \\
\text { Dimension }\end{array}$ & $\begin{array}{l}\text { Image } \\
\text { coefficient. }\end{array}$ & $\begin{array}{l}\text { Satisfaction } \\
\text { coefficient. }\end{array}$ & Equation $\mathrm{R}^{2}$ & $\begin{array}{l}\text { Equation } \\
\text { significance }(\mathrm{p})\end{array}$ \\
\hline 1 Competence & $0.821 \mathrm{p}<.001$ & N/A & 0.51 & $<.001$ \\
\hline 2 & $0.346 \mathrm{p}<.001$ & $0.431 \mathrm{p}<.001$ & 0.60 & $<.001$ \\
\hline 1 Warmth & $0.932 \mathrm{p}<.001$ & N/A & 0.77 & $<.001$ \\
\hline 2 & $0.442 \mathrm{p}<.001$ & $0.364 \mathrm{p}<.001$ & 0.55 & $<.001$ \\
\hline
\end{tabular}

Table (1) Tests of Base Line model for both Image dimensions

\begin{tabular}{|l|l|l|l|l|l|l|}
\hline Survey & 25 or under & $26-35$ & $36-45$ & $46-55$ & $56-65$ & Over 65 \\
\hline Warmth & 6.3 & 28.8 & 20.7 & 23.4 & 18.9 & 1.8 \\
\hline Competence & 3.7 & 30.8 & 28.0 & 23.4 & 13.1 & 9.0 \\
\hline
\end{tabular}

Table (2) Age profile of each sample

\begin{tabular}{|l|l|l|l|l|l|l|l|}
\hline $\begin{array}{l}\text { Image } \\
\text { Dimension }\end{array}$ & $\begin{array}{l}\text { Image } \\
\text { coeff. }\end{array}$ & Age coeff. & $\begin{array}{l}\text { Age } x \\
\text { Image } \\
\text { coeff. }\end{array}$ & $\begin{array}{l}\text { Satisfaction. } \\
\text { Coeff. }\end{array}$ & $\begin{array}{l}\text { Age } x \\
\text { Satisfaction } \\
\text { Coeff. }\end{array}$ & $\begin{array}{l}\text { Equation } \\
\mathrm{R}^{2}\end{array}$ & $\begin{array}{l}\text { Equation } \\
\text { sig. }(\mathrm{p})\end{array}$ \\
\hline Competence & $\begin{array}{l}0.97 \\
\mathrm{p}=.005\end{array}$ & $\begin{array}{l}0.05 \\
\mathrm{p}=0.27\end{array}$ & $\begin{array}{l}-0.19 \\
\mathrm{p}=0.016\end{array}$ & $\begin{array}{l}0.22 \\
\mathrm{p}=0.34\end{array}$ & $\begin{array}{l}0.072 \\
\mathrm{p}=0.28\end{array}$ & 0.63 & $<.001$ \\
\hline Warmth & -0.42 & 0.19 & 0.27 & $\begin{array}{l}1.56 \\
\mathrm{p}=0.001\end{array}$ & $\begin{array}{l}-0.36 \\
\mathrm{p}<.001\end{array}$ & 0.68 & $<.001$ \\
& $\mathrm{p}=.19$ & $\mathrm{p}<.001$ & $\mathrm{p}=.005$ & $\mathrm{p}<.001$ & \\
\hline
\end{tabular}

Table (3) The Moderating Effect of Employee Age on our Base Model

\begin{tabular}{|l|l|l|l|l|l|l|l|}
\hline $\begin{array}{l}\text { Image } \\
\text { Dimension }\end{array}$ & $\begin{array}{l}\text { Image } \\
\text { coeff. }\end{array}$ & $\begin{array}{l}\text { Gender } \\
\text { coeff. }\end{array}$ & $\begin{array}{l}\text { Gender } x \\
\text { Image } \\
\text { coeff. }\end{array}$ & $\begin{array}{l}\text { Satisfaction } \\
\text { coeff. }\end{array}$ & $\begin{array}{l}\text { Gender } x \\
\text { Satisfaction } \\
\text { coeff. }\end{array}$ & $\begin{array}{l}\text { Equation } \\
\mathrm{R}^{2}\end{array}$ & $\begin{array}{l}\text { Equation } \\
\text { sig. }(p)\end{array}$ \\
\hline Warmth & -0.20 & $\begin{array}{l}-2.49 \\
p=0.14\end{array}$ & $\begin{array}{l}0.37 \\
p=.17\end{array}$ & $\begin{array}{l}1.34 \\
p=0.001\end{array}$ & $\begin{array}{l}-0.66 \\
p=0.009\end{array}$ & 0.61 & $<.001$ \\
\hline
\end{tabular}

Table (4) The Moderating Effect of Gender on one Base Model 


\begin{tabular}{|l|c|c|c|}
\hline Question & $\begin{array}{l}\text { Mean response: } \\
\text { males }\end{array}$ & $\begin{array}{l}\text { Mean response: } \\
\text { females }\end{array}$ & $\begin{array}{l}\text { Significance of } \\
\text { difference (2 tailed) }\end{array}$ \\
\hline $\begin{array}{l}\text { I share the same work } \\
\text { values as my } \\
\text { colleagues }\end{array}$ & 5.14 & 4.51 & .026 \\
\hline $\begin{array}{l}\text { I share the same work } \\
\text { goals as my colleagues }\end{array}$ & 5.20 & 4.37 & .005 \\
\hline $\begin{array}{l}\text { I share the same work } \\
\text { attitudes as my } \\
\text { colleagues }\end{array}$ & 5.07 & 4.39 & .013 \\
\hline $\begin{array}{l}\text { I feel energetic in my } \\
\text { work }\end{array}$ & 4.96 & 4.15 & .013 \\
\hline $\begin{array}{l}\text { I am enthusiastic in my } \\
\text { work }\end{array}$ & 5.07 & 4.29 & .013 \\
\hline
\end{tabular}

Table (5) Gender Differences on Engagement items

\begin{tabular}{|l|l|l|l|l|l|l|l|}
\hline $\begin{array}{l}\text { Image } \\
\text { Dimension }\end{array}$ & $\begin{array}{l}\text { Image } \\
\text { coeff. }\end{array}$ & $\begin{array}{l}\text { Exper. } \\
\text { coeff. }\end{array}$ & $\begin{array}{l}\text { Exper. } x \\
\text { Image } \\
\text { coeff. }\end{array}$ & $\begin{array}{l}\text { Satisfaction. } \\
\text { coeff. }\end{array}$ & $\begin{array}{l}\text { Exper. } x \\
\text { Satisfaction } \\
\text { coeff. }\end{array}$ & $\begin{array}{l}\text { Equation } \\
\mathrm{R}^{2}\end{array}$ & $\begin{array}{l}\text { Equation } \\
\text { sig. }(\mathrm{p})\end{array}$ \\
\hline Competence & $\begin{array}{l}1.20 \\
\mathrm{p}=.0005\end{array}$ & $\begin{array}{l}0.027 \\
\mathrm{p}=0.523\end{array}$ & $\begin{array}{l}-0.17 \\
\mathrm{p}=0.010\end{array}$ & $\begin{array}{l}0.113 \\
\mathrm{p}=0.73\end{array}$ & $\begin{array}{l}0.070 \\
\mathrm{p}=0.26\end{array}$ & 0.65 & $<.001$ \\
\hline Warmth & 0.11 & $\begin{array}{l}0.184 \\
\mathrm{p}=.0001\end{array}$ & $\begin{array}{l}0.27 \\
\mathrm{p}=.005\end{array}$ & $\begin{array}{l}1.41 \\
\mathrm{P}=.0009\end{array}$ & $\begin{array}{l}0.076 \\
\mathrm{p}=.41\end{array}$ & 0.76 & $<.001$ \\
& $\mathrm{p}=.82$ & $\mathrm{p}=.000$ & \\
\hline
\end{tabular}

Table (6) The Moderating Effect of Work Experience on our Base Model

\begin{tabular}{|l|l|l|l|l|l|l|l|}
\hline $\begin{array}{l}\text { Image } \\
\text { Dimension }\end{array}$ & $\begin{array}{l}\text { Image } \\
\text { coeff. }\end{array}$ & $\begin{array}{l}\text { Contact } \\
\text { coeff. }\end{array}$ & $\begin{array}{l}\text { Contact } x \\
\text { Image } \\
\text { coeff. }\end{array}$ & $\begin{array}{l}\text { Satisfaction } \\
\text { coeff. }\end{array}$ & $\begin{array}{l}\text { Contact } x \\
\text { Satisfaction } \\
\text { coeff. }\end{array}$ & $\begin{array}{l}\text { Equation } \\
\mathrm{R}^{2}\end{array}$ & $\begin{array}{l}\text { Equation } \\
\text { sig. }(\mathrm{p})\end{array}$ \\
\hline Warmth & $\begin{array}{l}1.16 \\
\mathrm{p}=.005\end{array}$ & $\begin{array}{l}-0.240 \\
\mathrm{p}=0.124\end{array}$ & $\begin{array}{l}-0.56 \\
\mathrm{p}=.045\end{array}$ & $\begin{array}{l}-0.50 \\
\mathrm{p}=0.19\end{array}$ & $\begin{array}{l}0.626 \\
\mathrm{p}=0.016\end{array}$ & 0.59 & $<.001$ \\
\hline
\end{tabular}

Table (7) The Moderating Effect of Having Customer Contact on one Base Model

\begin{tabular}{|l|c|c|c|}
\hline Trait & $\begin{array}{l}\text { Mean response: } \\
\text { customer contact }\end{array}$ & $\begin{array}{l}\text { Mean response: no } \\
\text { customer contact }\end{array}$ & $\begin{array}{l}\text { Significance of } \\
\text { difference (2 tailed) }\end{array}$ \\
\hline Supportive & 3.82 & 3.60 & .002 \\
\hline Trustworthy & 3.72 & 3.15 & .005 \\
\hline Agreeable & 3.56 & 2.85 & .003 \\
\hline Open & 3.53 & 2.82 & .003 \\
\hline Socially responsible & 3.64 & 3.12 & .003 \\
\hline
\end{tabular}

Table (8) Differences on Warmth traits between those with Customer Contact and those without 


\begin{tabular}{|l|l|l|l|l|l|l|l|}
\hline $\begin{array}{l}\text { Image } \\
\text { Dimension }\end{array}$ & $\begin{array}{l}\text { Image } \\
\text { coeff. }\end{array}$ & Age coeff. & $\begin{array}{l}\text { Age. } x \\
\text { Image } \\
\text { coeff. }\end{array}$ & $\begin{array}{l}\text { Satisfaction. } \\
\text { coeff. }\end{array}$ & $\begin{array}{l}\text { Age } x \\
\text { Satisfaction } \\
\text { coeff. }\end{array}$ & $\begin{array}{l}\text { Equation } \\
R^{2}\end{array}$ & $\begin{array}{l}\text { Equation } \\
\text { sig. }(p)\end{array}$ \\
\hline Intellectual & -0.60 & 0.200 & 0.22 & 1.40 & -0.33 & .31 & $<.000$ \\
& $p=0.17$ & $p=.0019$ & $p=.08$ & $p=.001$ & $p=.006$ & & \\
\hline Social & -0.12 & 0.21 & 0.207 & 1.36 & -0.358 & .52 & $<.000$ \\
& $p=0.76$ & $p=.0004$ & $p=.078$ & $p=.0005$ & $p=.0012$ & & \\
\hline Affective & -0.35 & 0.089 & 0.258 & 1.27 & -0.255 & .72 & $<.000$ \\
& $p=0.27$ & $p=0.051$ & $p=.0064$ & $p<.001$ & $p=.0036$ & & \\
\hline
\end{tabular}

Table (9) The Moderating Effect of Age on our Base Model for Warmth to Predict Engagement Facets

\begin{tabular}{|l|l|}
\hline \multicolumn{1}{|c|}{ Hypothesis } & \\
\hline $\begin{array}{l}\text { H1a The more positive employee views are } \\
\text { of their employer's image, the greater their } \\
\text { satisfaction }\end{array}$ & Fully Supported \\
\hline $\begin{array}{l}\text { H1b The more positive employee views are } \\
\text { of their employer's image, the greater their } \\
\text { engagement. }\end{array}$ & Fully Supported \\
\hline $\begin{array}{l}\text { H2 The greater is employee satisfaction, the } \\
\text { greater their engagement }\end{array}$ & Fully Supported \\
\hline $\begin{array}{l}\text { H3 The effects of employee views of their } \\
\text { employer's image on their engagement are } \\
\text { mediated by their satisfaction. }\end{array}$ & Fully Supported \\
\hline $\begin{array}{l}\text { H4 The effects of employer image will vary } \\
\text { with the dimension of brand image }\end{array}$ & $\begin{array}{l}\text { Somewhat supported in that some effects } \\
\text { were similar while others differed }\end{array}$ \\
\hline $\begin{array}{l}\text { H5 The relationships between employer } \\
\text { image and both employee satisfaction and } \\
\text { engagement can be influenced by employee } \\
\text { specific factors. }\end{array}$ & $\begin{array}{l}\text { Supported for some employee factors and } \\
\text { more generally for Warmth than for } \\
\text { Competence }\end{array}$ \\
\hline
\end{tabular}

Table (10) A Summary of Hypotheses 
Figure (1) Base line model of Employer Branding Effect
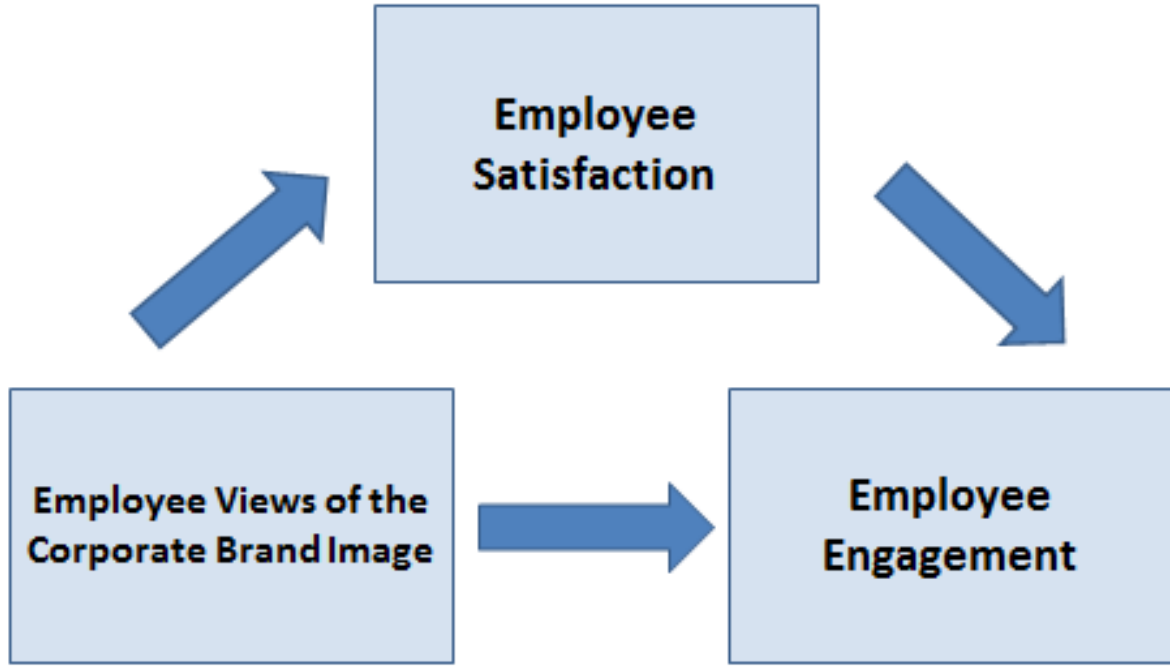

Figure (2) Moderated mediation model to test the influence of employee variables on the base model

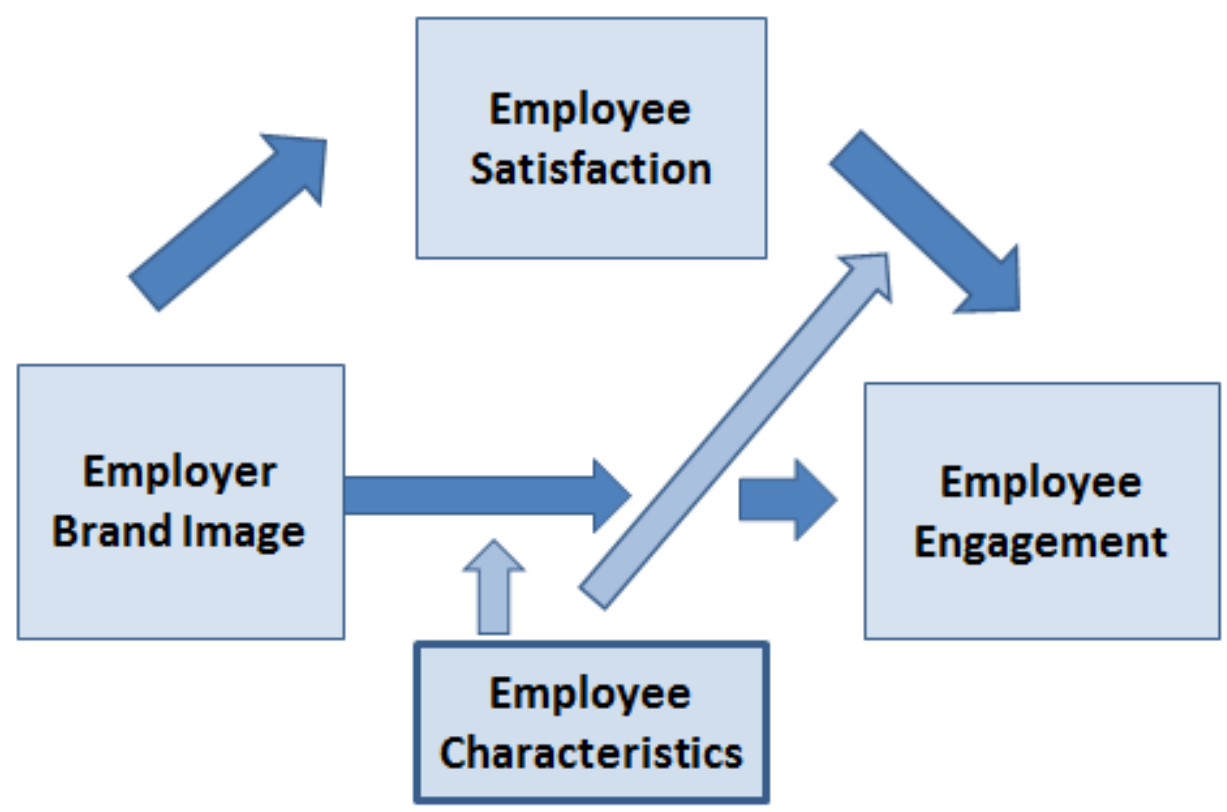

